\title{
Syntactic Rhythm of Political Speeches as a Psycholinguistic Tool of Suggestive Influence
}

\section{Синтаксичний ритм політичних промов як психолінгвістичний інструмент сугестивного впливу}

\author{
Alla Martynyuk \\ Dr. in Philology, \\ Professor
}

\author{
Алла Мартинюк \\ доктор філологічних наук, \\ професор
}

E-mail: allamartynyuk@ukr.net orcid.org/0000-0003-2804-3152

\begin{abstract}
Alina Ponikaryova
Ph.D. in Philology,

Senior Lecturer
\end{abstract}

\author{
Аліна Понікарьова \\ кандидат філологічних наук, \\ старший викладач
}

E-mail: alinaponikaryova@karazin.ua orcid.org/0000-0001-8450-7092

V.N. Karazin Kharkiv

National University

4, Maidan Svobody, Kharkiv,

Ukraine, 61022
Харківський національний університет імені В.Н. Каразіна $\checkmark$ майдан Свободи, 4, м. Харків, Україна, 61022

Original manuscript received February 13, 2018

Revised manuscript accepted September 14, 2018

\section{ABSTRACT}

This paper addresses the problem of linguistic means of suggestive influence. Suggestive influence is viewed as engrafting into the individuals' psychic certain ideas, feelings, emotions, or other psychophysiological states bypassing their critical rational thinking. It is stated that suggestion works at the level of structure, specifically, at the level of syntactic arrangement of speech, creating persistent rhythmic-syntactic patterns that grow familiar and build anticipation switching off rationality, and making comprehension subconscious. The study is based on the structural and cognitive analysis of the syntax of Obama's and 
Cameron's political speeches. The cognitive analysis employs the instruments provided by L. Talmy's FIGURE-GROUND construal. The analysis reveals that the syntax of the analysed political speeches is based on the three structural-semantic patterns of arranging predications: the structural-semantic incorporation, the semantic incorporation and the chain attachment. The structural-semantic incorporation and the chain attachment are underpinned by the linear cognitive scheme of changing the listeners' focus of attention. The linear scheme is natural for the development of discourse. It sets the prevailing rhythmic-syntactic pattern of a political speech. Since this pattern is predictable, it serves to automatize perception and weaken rational evaluation of the speech content. The semantic incorporation is underpinned by the non-linear cognitive scheme of changing the listeners' focus of attention. This scheme goes contrary to the natural development of discourse. It breaks the prevailing rhythmic-syntactic pattern and makes the listeners concentrate on what is being said. The change of patterns ensures the listeners' interest to the speech.

Key words: suggestive influence, attention, FIGURE / GROUND construal, syntax, rhythm, rhythmic-syntactic pattern, political speech.

\section{Introduction}

Suggestive influence can be best explained in V.M. Bekhterev's (2001: 24) words, as engrafting into the individuals' psychic certain ideas, feelings, emotions, or other psychophysiological states bypassing their inner self, bypassing their personality capable of comprehension and criticism.

The interest in suggestive influence in social sciences including linguistics has never ceased (see, for example, Cherepanova, 2002; Grinder \& Pucelik, 2012; Bandler, 2014; Dilts, 1999; 2017; Kalita, 2015; Sternin, 2015; Shelestyuk, 2008) since J. Grinder and R. Bandler introduced the kind of suggestive psychotherapy called neurolinguistic programming (1975). This interest can be easily explained by the fact that such research has a huge practical relevance, as it provides effective tools to regulate social behaviour.

Yet, up to now there is a lot of uncertainty as to what language means are specifically engaged in executing suggestive influence. Most scholars include in this list pragmatically charged lexical items like metaphors, similes, hyperboles, emotionally coloured words, paraphrases, euphemisms, and also pragmatic types of utterance like imperatives. One can object that though pragmatically charged linguistic 
units are primarily engaged in evoking emotional states, they do have some denotative meaning and thus can trigger rational inference. As for imperatives, they primarily appeal to the will of the addressees urging them to take some action, and this can involve a free will rational choice. So the listed linguistic items do not qualify as being specialised in executing suggestive influence.

In psycholinguistics the issue of suggestion is linked to experimental studies of correlation between phrase / sentence form and information structure in terms of topic-focus relations (see, for example, Almor 1999; Carlson et al., 2009; Clifton \& Ferreira, 1987; Lambrecht, 1994; 2001).

We also believe that suggestion works at the level of structure not meaning, specifically, at the level of syntactic arrangement of speech, creating persistent rhythmic-syntactic patterns that grow familiar and build anticipation switching off rationality, making comprehension subconscious (Martynyuk, 2015). Put within a familiar rhythmic-syntactic pattern the ideas are being processed automatically, subconsciously without much of critical assessment. A break of such a pattern makes the listeners focus on what is being said, «brings them into consciousness»». These rhythmic-syntactic patterns can be filled with any lexical/pragmatic content, including the above mentioned linguistic units, but these units acquire suggestive power only as parts of a persistent rhythmic-syntactic pattern.

In the on-going discourse sequences of predications (simple sentences or clauses of composite sentences) of political speeches replace each other flooding the listeners with the flow of new information, occupying their focus of attention for a very brief moment. And since political speeches are aimed at regulating the listeners' social behaviour - persuading and/or urging them to vote for some particular politician or support his/her political project, it's only natural to suppose that rhythmic-syntactic arrangement of predications in political speeches plays its role in determining the patterns of shifting the focus of the listeners' attention and with it the flow consciousness.

\section{Methods and techniques of the research}

The goal of the study is to discover suggestive potential of the rhythmic-syntactic patterns in the political speeches. This goal is achieved through the following objectives: 1) to identify the structural- 
semantic schemes of arrangement of predications which set the rhythmicsyntactic patterns of the political speeches; 2) to reveal the cognitive schemes of shifting the listener's focus of attention that underpin these rhythmic-syntactic patterns.

To achieve the stated goal and objectives we first have to define and interconnect the two key notions of our research - attention and rhythm.

In this paper attention is addressed in W. Chafe's (1994) interpretation as the «focus of consciousness». W. Chafe departs from the assumption that consciousness is the locus of humans' on-going interaction with the environment as well as the site for inner thought and feeling, the locus of remembering, imagining, evaluating, and speaking, and thus central to the functioning of the mind (ibid.: 36-37), and addresses consciousness as «an active focusing on a small part of the conscious being's self-centred model of the surrounding world» (ibid.: 28). According to W. Chafe, the active focus of consciousness is surrounded by a periphery of semiactive information that provides a context for it (ibid.: 29) and any information that is «neither fully active nor demonstrably semiactive» is called inactive (ibid.: 55).

Naturally, the focus of consciousness is dynamic, it is moving constantly from one item of information to the next: «one focus of active information is replaced by another, each finding coherence in the contexts provided by the surrounding semiactive information» (ibid.: 30 ).

To specify syntactic nature of the verbal utterance appearing in the focus of attention of the listeners of a political speech, we turn to W. Chafe's notion of an intonation unit, i.e. «a unit of mental and linguistic processing $\langle\ldots\rangle$ that seems to be of exactly the right size to be processed» (ibid.: 55). This limited activation «allows a person to interact with the surrounding world in a maximally productive way, for it would hardly be useful to activate everything a person knew at once in its entirety» (ibid.: 29). W. Chafe thinks of a typical intonation unit as having the form of a predication (in his terms - clause), verbalising the idea of an event or state. And «each such idea is active, or occupies a focus of consciousness, for only a brief time, each being replaced by another idea at roughly one-to-two-second intervals» (ibid.: 66) thus changing its status from active into semiactive and, finally, inactive.

Our sample consists of 8,310 predications equal to 1,057 simple sentences and 3,150 clauses of composite sentences $(2,610$ complex 
and 540 compound) extracted from Obama's political speeches and also 1,163 simple sentences and 2,940 clauses of composite sentences (2,400 complex and 540 compound) extracted from Cameron's political speeches given during the period of 2010-2015.

Within this framework a political speech can be seen as a sequence of intonation units equal to predications changing each other in the flow of discourse. In the on-going discourse each new coming predication supplies ideas filling the information gaps created by the preceding one. So the idea of each such predication occupies the focus of the listeners' attention for a brief interval before it is replaced by another idea represented by the consequential predication, changing the status of the previous one into semiactive and, eventually, inactive. We call this scheme of changing the focus of attention the linear cognitive scheme. The linear scheme is natural for the development of the ongoing discourse.

Applying the instruments of cognitive analysis, specifically the tools provided by L. Talmy's (1975) FIGURE-GROUND construal, we come to reveal that structural-semantic arrangement of predications of complex sentences can also set the non-linear scheme of shifting the focus of attention. To explain the FIGURE-GROUND construal we refer to L. Talmy's (ibid.) account of semantic relations between the temporal events expressed by the clauses of a complex sentence with a subordinate clause of time, e.g., He exploded after he touched the button. L. Talmy discusses such relations in terms of FIGURE/ GROUND where a FIGURE event is «a variable whose particular value receives characterisation with respect to a GROUND event considered as a reference-point set in a temporal reference frame» (ibid.: 423). L. Talmy assigns the GROUND interpretation to the button-touching event, expressed by the subordinate clause of time, and the FIGURE interpretation - to the explosion-event, expressed by the main clause. The GROUND is addressed as a fixed reference point, establishing the location in time of the FIGURE as a more salient occurrence with respect to the other (ibid.). Later in the article L. Talmy parallels complex sentences with the subordinate clauses of time like She departed after he arrived / He had two affairs while he was married / She rested until he arrived and those with the subordinate clauses of cause and concession like We stayed home because it was raining / We went out even though it was raining (ibid.: 427). In all these cases the more important idea 
belongs in the main clause. It means that if the main clause precedes the subordinate clause in the flow of discourse such sequence breaks the linear scheme of moving the focus of attention and sifts it back to process the more salient information. This scheme of changing the focus of attention is called the non-linear cognitive scheme.

We believe that the linear and non-linear cognitive schemes set two different rhythmic-syntactic patterns of the speech flow.

In a broad perspective rhythm is seen as part of all human activities and «may be considered as an organizing principle that structures events» (Magne et al., 2004: 2004). ). In cognitive poetics rhythm is treated in terms of parallel syntactic structures filled with verbal texture creating rich imagery, e.g., imitating heartbeat to shape «the cardiogram of the text» (Vorobyova, 2017: 471).

In dictionaries rhythm is defined as: a strong pattern of sounds, words, or musical notes that is used in music, poetry, and dancing; a regular movement or pattern of movements; a regular pattern of change, especially one that happens in nature (Cambridge English dictionary, s.a.); a strong, regular repeated pattern of movement or sound; the measured flow of words and phrases in verse or prose as determined by the relation of long and short or stressed and unstressed syllables; a regularly recurring sequence of events or processes; a harmonious sequence or correlation of colours or elements (Oxford dictionaries, s.a.); an ordered recurrent alternation of strong and weak elements in the flow of sound and silence in speech movement; fluctuation, or variation marked by the regular recurrence or natural flow of related elements; a regularly recurrent quantitative change in a variable biological process (Merriam-Webster, s.a.).

Departing from dictionary definitions of rhythm as a movement marked by the regular succession of strong and weak elements, or other opposite conditions we claim that the linear and non-linear schemes of shifting the focus of attention can be treated as two rhythmicsyntactic patterns with the two opposite syntagmatic configurations of the strong (FIGURE) and weak (GROUND) elements: $[\mathrm{G} \rightarrow[\mathrm{F}]]:$ : $[[F] \leftarrow G]$. The linear scheme shifts the focus of the listeners' attention progressively together with the unfolding syntagmatic chain of speech while the non-linear scheme shifts it regressively.

We put forward a hypothesis that the syntax of political speeches (as, probably, any syntax) has two possible rhythmic-syntactic patterns. 
Syntactic Rhythm of Political Speeches as a Psycholinguistic Tool...

And these patterns set the linear and non-linear cognitive schemes of changing the focus of attention. The linear scheme serves to automatize perception and weaken rational evaluation of the content of speech. The non-linear scheme, on the contrary, «brings the listeners into consciousness», making them concentrate on what is being said and critically evaluate it. The change of patterns ensures the listeners' interest to the speech.

To prove the hypothesis we undertake a two-step analysis. The first step of the methodological procedure involves a structural-semantic analysis of the syntax of Obama's and Cameron's speeches to reveal the patterns of the structural-semantic arrangement of the predications. This analysis takes into consideration: 1) semantic relations between the states/events represented by the predications; 2) the order of the predications in the syntagmatic chain (whether it is fixed or non-fixed); 3) the degree of structural-semantic dependence between the predications: whether it is a separate simple sentence or part of a compound/complex sentence. The second step presupposes handling the data with the tools provided by L. Talmy's (1975) FIGURE-GROUND construal to reveal the linear and non-linear cognitive schemes of shifting the focus of attention.

\section{Results and discussion}

The structural-semantic arrangement of the predications in the analysed political speeches follows the three patterns that we call: 1) the structural-semantic incorporation, 2) the semantic incorporation; 3) the chain attachment. The types were first revealed in (Martynyuk \& Ponikaryova, 2013).

The structural-semantic incorporation is typical of the complex sentences with a grammatically fixed sequential order of the structurally and semantically interdependent clauses completing each other's ideas. This type of structural-semantic arrangement is found in the complex sentences with the subordinate clauses of subject (example 1), predicative (example 2), object (example 3), and attribute (example 4). In all the cases, with the exception of a complex sentence with a subject subordinate clause, the main clause is the initial clause of the sentence:

(1) What we see is a process of radicalisation. (Cameron at Cameron and Obama press conference, March 14, 2012) 
(2) Our free enterprise system is what drives innovation. (President Barack Obama's state of the union address, January 25, 2011)

(3) I believe our relationship can be a win-win. (Cameron at Cameron and Obama press conference, July 20, 2010)

(4) Our declaration sets out a clear commitment that transition will begin in early 2011. (David Cameron's press conference at the NATO summit in Lisbon, November 20, 2010)

The clauses of the complex sentences united by the structuralsemantic incorporation do not make much sense on their own and can be understood only in combination, as a whole. Since the order of clauses in such sentences is fixed, the pattern of the structural-semantic incorporation moves the focus of the listeners' consciousness in a linear way: from the incomplete idea represented by a preceding clause to its completion (as in examples 1-3) and/or development (as in example 4) represented by a consequential clause. The linear pattern holds true no matter how many predications we have - two (examples 1-4), or five (example 5) or whether the sentence begins with the main clause (examples 2-5) or with a subordinate clause (example 1):

(5) The health insurance law we passed last year will slow these rising costs, which is part of the reason that nonpartisan economists have said that repealing the health care law would add a quarter of a trillion dollars to our deficit. (President Barack Obama's state of the union address, January 25, 2011)

Within the structural-semantic incorporation the GROUND state/ event is always expressed by the preceding clause in the syntagmatic chain and the FIGURE state/event - by the sequential clause. In the ongoing discourse the status of the FIGURE state/event changes into that of the GROUND state/event with every new coming predication. So the scheme of changing the focus of attention is always linear: $[\mathrm{G} \rightarrow[\mathrm{F}]]$ (examples $1-4) ;[\mathrm{G} \rightarrow[\mathrm{F} 1 / \mathrm{G}] \rightarrow \mathrm{F} 2 / \mathrm{G} \rightarrow[\mathrm{F} 3 / \mathrm{G} \rightarrow[\mathrm{F} 4 / \mathrm{G} \rightarrow[\mathrm{F} 5]]]]$ (example 5); brackets represent clauses united in a sentence.

The semantic incorporation characterises complex sentences with the non-fixed sequential order of clauses. The clauses of such complex sentences show some degree of structural completeness that allows them to change their position in the syntagmatic chain. At the same time, subordinate clauses of such complex sentences cannot stand alone because taken separately they do not provide a complete thought. This type of structural-semantic arrangement is found in the complex 
Syntactic Rhythm of Political Speeches as a Psycholinguistic Tool...

sentences with the adverbial subordinate clauses of time (example 6), condition (example 7), cause-effect (example 8), and concession (example 9):

(6) This year, our civilians will forge a lasting partnership with the Iraqi people, while we finish the job of bringing our troops out of Iraq. (President Barack Obama's state of the union address, January 25, 2011)

(7) You cannot build strong economies, open societies and inclusive political systems if you lock out women. (David Cameron's speech to the Conservative Party conference 2012, October 10, 2012)

(8) Because of a diplomatic effort to insist that Iran meet its obligations, the Iranian government now faces tougher sanctions, tighter sanctions than ever before. (President Barack Obama's state of the union address, January 25, 2011)

(9) Whether they are violent in their means or not, we must make it impossible for the extremists to succeed. (David Cameron's speech on radicalisation and Islamic extremism, February 5, 2011)

Unlike the structural-semantic incorporation, the pattern of semantic incorporation can move the focus of the listeners' attention in a non-linear way.

In all the examples the relations between the events or states denoted by the subordinate clauses and the main clauses can be explained in terms of FIGURE-GROUND relations where the GROUND interpretation is assigned to the states / events of the subordinate clauses that set the frames for the understanding of the more salient states/ events of the main clauses interpreted as the FIGURE.

Thus in example 6 the event of bringing the US troops out of Iraq sets the temporal reference frame (and maybe even conditional frame since another possible interpretation is that the event expressed by the main clause can only take place if the US troops are brought out of Iraq) for the event of forging a lasting partnership with the Iraqi people. In a similar way, a subordinate clause of condition, as in example 7 , sets the conditional frame (ensuring women's participation) for the fulfilment of the event expressed by the main clause (building strong economies, open societies and inclusive political systems). In example 8 the subordinate clause sets the cause frame (diplomats made effort to insist that Iran meet its obligations) for the event expressed in the main clause (the Iranian government now faces tougher sanctions, tighter sanctions than 
ever before). In example 9 the subordinate clause sets the concession frame denoting circumstances which might be expected to prevent the action of the main clause but do not (the violence of extremism does not stop England from fighting it).

In the context of the on-going discourse the focus of attention of the listeners will always be on the FIGURE, since it represents more salient information. So in the type of the structural-semantic arrangement of the predications of a complex sentence called the semantic incorporation the scheme of changing the focus of attention will depend on the position of the main clause. If the main clause follows the subordinate clause, as in examples 8,9 , the scheme of changing the focus of attention is linear: $[\mathrm{G} \rightarrow[\mathrm{F}]]$. If the main clause precedes the subordinate clause, as in examples 6,7 , the scheme is non-linear: $[[F] \leftarrow G]$. If the GROUND is presented to the listeners later than the FIGURE, the listeners have to move their focus of attention back to the FIGURE to be able to fully understand the idea. At the same time they have to keep the GROUND in the scope of attention, since it sets the frame for understanding the idea expressed by the FIGURE. All this (at least for a brief moment in time) stops the linear movement of the focus of attention and reverses it making it non-linear.

The chain attachment connects simple sentences and clauses of coordination: the predications are structurally independent, expressing complete ideas; the sequential order of predications is fixed with the full stops put between simple sentences (example 10) and conjunctions between the units of coordinate sentences (examples 11, 12).

(10) The United States also strongly supports the universal rights of the Libyan people. That includes the rights of peaceful assembly, free speech, and the ability of the Libyan people to determine their own destiny. These are human rights. They are not negotiable. They must be respected in every country. And they cannot be denied through violence or suppression. (President Barack Obama's address on the violence in Libya, February 23, 2011)

It is obvious that with a sequence of simple sentences the GROUND state/event is always expressed by the preceding sentence in the syntagmatic chain and the FIGURE state/event - by the sequential sentence. In the on-going discourse the status of the FIGURE state/event changes into that of the GROUND state/event with every new coming sentence, in a natural, linear way. 
Syntactic Rhythm of Political Speeches as a Psycholinguistic Tool...

Compound sentences can be built on both coordinate and subordinate semantic relations. The chain attachment based on the semantic relations of coordination sets the linear scheme of shifting the focus of attention where the information given in a preceding clause provides the GROUND for interpreting the states/events represented by a sequential clause functioning as the FIGURE: $[[\mathrm{G}] \rightarrow[\mathrm{F}]]$ :

(11) This will put advanced technologies in the hands of our troops and it will mean more jobs for workers in both our countries. (Obama at Cameron and Obama press conference, July 20, 2010)

(12) We increased spending dramatically for two wars and an expensive prescription drug program - but we didn't pay for any of this new spending. (President Barack Obama's address on the violence in Libya, February 23, 2011)

Subordinate semantic relations of coordination include those of: 1) cause and effect (example 13); 2) concession (example 14); 3) time (example 15):

(13) There will be tough fighting ahead, and the Afghan government will need to deliver better governance. (President Barack Obama's state of the union address, January 25, 2011)

(14) We may have differences in policy, but we all believe in the rights enshrined in our Constitution. (President Barack Obama's state of the union address, January 25, 2011)

(15) Thirty-seven days later, Plan B succeeded, and the miners were rescued. (President Barack Obama's state of the union address, January 25, 2011)

Since in all the examples the initial predication semantically correlates with the corresponding subordinate clause (of cause-effect, concession, and time), setting the frame of reference for the events of the sequential predication, the scheme of shifting the focus of attention is linear in all the cases: $[[\mathrm{G}] \rightarrow[\mathrm{F}]]$.

The results of the analysis bring us to the conclusion that the structural-semantic incorporation and chain attachment provide the linear scheme of the GROUND-FIGURE motion, shifting the listeners' focus of attention progressively along with the natural flow of discourse. The semantic incorporation sets the non-linear scheme of the GROUNDFIGURE motion in case the main clause precedes the subordinate. This non-linear scheme is shifting the listeners' focus of attention in the direction opposite to the natural unfolding of the on-going discourse. 
According to our data, the linear scheme of shifting the focus of the listeners' attention prevails in the speeches of both the politicians (85.7\% against $14.3 \%$ in Obama's speeches and $89.6 \%$ against $10.4 \%$ in Cameron's speeches. In other words, the linear scheme sets the basic rhythmic pattern of their political speeches.

The linear movement of the focus of attention is natural and hence predictable. In O.M. Brik's (1927) words, predictable syntactic patterns set the basic rhythmic pattern of a speech genre being entrenched in the consciousness even before its materialisation, before it is being verbalised. Being predictable such patterns create anticipation. They build the listeners' expectations of what is to come. Since processing such patterns do not require much concentration of attention (Tynyanov, 2007: 37), they facilitate comprehension of speech, automatize it. And in this sense the linear rhythmic-syntactic pattern is suggestive.

But when this predictable rhythmic-syntactic pattern breaks and another rhythmic-syntactic pattern comes to substitute it, the listeners are brought into consciousness since something non-anticipated requires more effort to process (Brik, 1927: 33; Tynyanov, 2007: 49; Shklovsky, 1983: 14).

The non-linear cognitive scheme that shifts the focus of the listeners' attention in the direction opposite to the unfolding syntagmatic chain of speech is not natural for the on-going discourse and hence it is not anticipated. Non-linear scheme underpins complex sentences based on the causal relations between the clauses where subordinate clauses are understood as «motives» (temporal, conditional, cause-effect, or concession reference frames) of the states/events expressed in the main clauses. And processing such sentences presupposes logical inferences built on causation. To perform this task the listeners should keep these sentences in the focus of consciousness for a longer period. The switch between the linear and non-linear rhythmic-syntactic patterns controls the listeners' focus of attention, stimulating their interest to the speech.

\section{Conclusions}

The results of this study show that the predications (simple sentences and clauses of composite sentences) of the analysed political speeches are arranged in the three basic structural-semantic patterns: 
Syntactic Rhythm of Political Speeches as a Psycholinguistic Tool...

1) the structural-semantic incorporation; 2) the semantic incorporation; 3) the chain attachment.

The structural-semantic incorporation and the chain attachment are underpinned by the linear cognitive scheme of shifting the focus of attention that sets the prevailing rhythmic-syntactic pattern of a political speech shifting the listeners' focus of attention progressively along with the natural flow of discourse. Since the linear pattern is predictable, it serves to automatize perception and weaken rational evaluation of the content of speech, bypassing the conscious inner self. And in this sense the linear rhythmic-syntactic pattern is suggestive.

The semantic incorporation is underpinned by the non-linear cognitive scheme that shifts the listeners' focus of attention in the direction opposite to the natural unfolding of the on-going discourse. This scheme sets a new rhythmic-syntactic pattern which breaks the prevailing rhythmic-syntactic pattern of the speech and makes the listeners concentrate on the arguments represented in the clauses of composite sentences united by causal relations and critically evaluate them. The change of the patterns keeps the listeners' interest to the speech. Both patterns serve the main strategic goal of political speeches - persuading/urging the listeners to support the political leader.

The study opens perspectives for the further inquiry in the domain of cognitive underpinnings of attention shifts in communication: application of experimental methodology to test and develop the present findings; adaptation of the developed theoretical framework and methodology to investigation of other types of persuasive/suggestive discourse (advertising, publicist, psychotherapeutic, and religious).

\section{References}

Almor, A. (1999). Noun-phrase Anaphora and Focus: The Information Load Hypothesis. Psychological Review, 106(4), 748-765. http://dx.doi.org/10.1037/0033295X.106.4.748

Bandler, R. (2014). How to take change of your life: The user's guide to NLP. New York: HarperCollins Publishers.

Bandler, R., \& Grinder, J. (1975). The structure of magic. Palo Alto, California: Science and Behavior Books, Inc.

Bekhterev, V.M. (2001). Vnusheniye i yego rol v obschestvennoj zhizni [Suggestion and its role in social life]. Sankt-Petyerburg: Pityer [in Russian].

Brik, O.M. (1927). Ritm i sintaksis [Rhythm and syntax]. Novyj lyef - New lef, 6, 33-39 [in Russian].

Cameron and Obama press conference, July 20, 2010. Available at: https://www.gov. uk/government/speeches/joint-press-conference-with-president-barack-obama. 
Синтаксичний ритм політичних промов як психолінгвістичний...

Cameron and Obama press conference, March 14, 2012. Available at: https:// obamawhitehouse.archives.gov/the-press-office/2012/03/14/remarks-presidentobama-and-prime-minister-cameron-united-kingdom-joint-

Cambridge English dictionary. Available at: https://dictionary.cambridge.org/ dictionary/ english/rhythm/

Carlson, K., Dickey, M.W., Frazier, L., \& Clifton, C. (2009). Information structure expectations in sentence comprehension. Quarterly Journal of Experimental Psychology, 62(1), 114-139. doi: 10.1080/17470210701880171

Chafe, W. (1994). Discourse, consciousness, and time. Chicago: University of Chicago Press.

Cherepanova, I.Yu. (2002). Zagovor naroda. Kak sozdat silnyj politicheskij tekst [Plot against people. How to create the strong political text]. Moscow: KSP+ [in Russian].

Clifton, C., \& Ferreira, F. (1987). Discourse structure and anaphora: Some experimental results. In: M. Coltheart (ed.) Attention and Performance XII - The Psychology of Reading, (pp. 635-654). Hove: Lawrence Erlbaum.

David Cameron's press conference at the NATO summit in Lisbon, November 20, 2010. Available at: www.gov.uk/government/speeches/nato-summit-press-conference

David Cameron's speech on radicalisation and Islamic extremism, February 5, 2011. Available at: http://www.newstatesman.com/blogs/the-staggers/2011/02/terrorismislam-ideology

David Cameron's speech to the Conservative Party conference 2012, October 10, 2012. Available at: http://www.independent.co.uk/news/uk/politics/conservativeparty-conference-2012-in-birmingham-full-transcript-of-david-cameronsspeech-8205536.html/

Dilts, R. (1999). Sleight of mouth. The magic of conversational belief change. Capitola, CA: Meta Publications.

Dilts, R. (2017). Success factor modeling. Conscious leadership and resilience: Orchestrating innovation and fitness for the future, III. Santa Cruz, CA: Dilts Strategy Group.

Ilnytska, L.L. (2006). Anhlomovnyj suhestyvnyj dyskurs [English suggestive discourse]. Extended abstract of candidate's thesis. Kharkiv [in Ukrainian].

Grinder, J., \& Pucelik, F. (2013). Origins of neuro linguistic programming. Tonbridge: Crown House.

Kalita, A.A. (2015). Suggestivnyj potencial ritmicheskoj sistemy prozaicheskogo teksta [Subliminal potential of the prosaic text rhythmic system] Kohnitsiya. Komunikatsiya. Dyskurs - Cognition. Communication. Discourse, 11, 29-44 [in Russian]. doi: 10.26565/2218-2926-2015-11-03

Lambrecht, K. (1994). Information structure and sentence form: A theory of topic, focus, and the mental representations of the discourse referents. Cambridge: Cambridge University Press.

Lambrecht, K. (2001). A framework for the analysis of cleft constructions. Linguistics, 39(3), 463-516. doi.org/10.1515/ling.2001.021

Magne, C., et al. (2004). Comparison of rhythmic processing in language and music: An interdisciplinary approach. The journal of music and meaning, 3, 2004-2005.

Martynyuk, A.P. (2015). Kognitivno-kommunikativnyj instrumentarij analiza rechevogo vozdejstviya [Cognitive-communicative instruments of analysis of verbal influence]. Science and Education: A New Dimension. Philology, 68, 67-71 [in Russian]. 
Syntactic Rhythm of Political Speeches as a Psycholinguistic Tool...

Martynyuk, A.P., \& Ponikaryova, A.Yu. (2013). Kognitivno-kommunikativnyj instrumentarij analiza slozhnopodchinyennogo sintaksisa politicheskogo diskursa. [Cognitive-discursive tools of analysis of the complex syntax of English political discourse]. Kohnitsiya. Komunikatsiya. Dyskurs - Cognition. Communication. discourse, 7, 68-80 [in Russian]. doi: 10.26565/2218-2926-2013-07-05

Merriam-Webster dictionary. Available at: https://www.merriam-webster.com/ dictionary/rhythm

Oxford dictionaries. Available at: https://en.oxforddictionaries.com/definition/ rhythm

President Barack Obama's address on the violence in Libya, February 23, 2011. Available at: https://www.nytimes.com/2011/02/24/us/politics/24obama-statementlibya.html

President Barack Obama's state of the union address, January 25, 2011. Available at: http://www.americanrhetoric.com/barackobamaspeeches.htm

Shelestyuk, O.V. (2008). Rechevoye vozdejstviye: Ontologiya $i$ metodologiya issledovaniya [Verbal influence: Ontology and methodology of research]. Chelyabinsk: OOO «Entsiklopediya» [in Russian].

Shklovsky, V. (1983). Iskusstvo kak priyom [Art as a figure]. O teorii prozy - On the theory of prose. (pp. 9-25). Moscow: Sovetskij pisatel [in Russian].

Sternin, I.A. (2015). Osnovy rechevogo vozdejstviya [Foundations of verbal influence] (3nd ed.). Moscow-Berlin: Direct-Media [in Russian].

Talmy, L. (1975). Figure and ground in complex sentences. Proceedings of the first annual meeting of the Berkeley Linguistics Society. (pp. 419-430).

Tomashevsky, B.V. (2002). Teoriya literatury. Poetika [Theory of literature. Poetics]. Moscow: Aspekt Press [in Russian].

Tynyanov, Yu.N. (2007). Problema stikhotvornogo yazyka [The problem of poetic language]. Moscow: KomKniga [in Russian].

Vorobyova, O.P. (2017). Haunted by Ambiguities Revisited: in Search of a Metamethod for Literary Text Disambiguation. Lege artis. Language yesterday, today, tomorrow. The Journal of University of SS Cyril and Methodius in Trnava, 2 (1), 428-496. doi: 10.1515/lart-2017-0011

\section{АНОТАЦІЯ}

у роботі розглянута проблема мовних засобів сугестивного впливу. Сугестивний вплив тлумачиться як вживляння у психіку індивідів певних ідей, почуттів, емочій або інших психофізіологічних станів в обхід їх критичного раціонального мислення. Стверджується, що сугестія реалізується на рівні структури, а саме, на рівні синтаксичного аранжування мовлення, яке створює стійкі ритміко-синтаксичні патерни, що стають звичними і очікуваними, відключаючи раціональне мислення і надаючи сприйняттю півсвідомого характеру. Дослідження грунтується на структурному та когнітивному аналізі синтаксису політичних промов Б. Обами та Д. Кемерона. У якості інструмента когнітивного аналізу використовується когнітивна модель ФІГУРА/ФОН Л. Талмі. Результати дослідження показують, що синтаксис аналізованих політичних промов зорганізується трьома структурно-синтаксичними 
патернами зв'язку між предикаціями: структурно-семантичним інкорпоруванням, семантичним інкорпоруванням та ланцюжковим приєднанням. Структурно-семантичне інкорпорування та ланцюжкове приєднання є втіленням лінійної когнітивної схеми зміни фокусу уваги реципієнтів промов. Лінійна схема відповідає природному розгортанню дискурсу. Вона задає базовий стійкий ритміко-синтаксичний патерн політичної промови. Оскільки цей ритміко-синтаксичний патерн $\epsilon$ передбачуваним, він автоматизує сприйняття й послаблює критичну оцінку змісту промови. Семантичне інкорпорування $\epsilon$ втіленням нелінійної когнітивної схеми зміну фокусу уваги реципієнтів. Ця схема не відповідає природному розгортанню дискурсу. Вона перериває стійкий ритміко-синтаксичний патерн і змушує реципієнтів сконцентруватися на змісті промови. Зміна ритміко-синтаксичного патерну підтримує інтерес реципієнтів до промови.

Ключові слова: сугестивний вплив, увага, когнітивна модель ФІГУРА/ $Ф О Н$, синтаксис, ритм, ритміко-синтаксичний патерн, політична промова.

\section{Мартынюк Алла, Поникарёва Алина. Синтаксический ритм политических речей как психолингвистический инструмент суггестивного воздействия}

\section{АННОТАЦИЯ}

В работе рассмотрена проблема речевых средств суггестивного воздействия. Суггестивное воздействие понимается как внедрение в психику индивидов определенных идей, чувств, эмоций или других психофизиологических состояний в обход их критического рационального мышления. Утверждается, что суггестия реализуется на уровне структуры, а именно, на уровне синтаксического аранжирования речи, создавая стойкие ритмико-синтаксические паттерны, становящиеся привычными и предсказуемыми, отключая рациональное мышление и придавая восприятию неосознанный характер. Исследование базируется на структурном и когнитивном анализе синтаксиса политических речей Б. Обамы и Д. Кемерона. В качестве инструмента когнитивного анализа используется когнитивная схема ФОН/ФИГУРА Л. Талми. Результаты анализа показывают, что исследуемые политические речи базируются на трех структурно-семантических паттернах аранжирования предикаций: структурно-семантическом инкорпорировании, семантическом инкорпорировании и цепочном присоединении. Структурно-семантическое инкорпорирование и цепочное присоединение воплощают линейную когнитивную схему смены фокуса внимания реципиентов. Линейная схема совпадает с 
Syntactic Rhythm of Political Speeches as a Psycholinguistic Tool...

естественным разворачиванием дискурса. Она задает доминирующий ритмико-синтаксический паттерн политической речи. Поскольку этот паттерн предсказуем, он автоматизирует восприятие $и$ отключает рациональное осмысление содержания речи. Семантическое инкорпорирование воплощает нелинейную когнитивную схему смены фокуса внимания реципиентов. Эта схема не соответствует природному разворачиванию дискурса. Она прерывает стойкий ритмико-синтаксический паттерн и заставляет реципиентов сконцентрироваться на смысле речи. Смена паттернов поддерживает интерес реципиентов к речи.

Ключевые слова: суггестивное воздействие, внимание, когнитивная схема ФИГУРА/ФОН, синтаксис, ритм, ритмико-синтаксический паттерн, политическая речь. 